\title{
Biochar dari Biomassa Kusambi, Akasia, dan Kayu Putih sebagai Media Semai Benih Selada (Lactuca Sativa L.)
}

\author{
Origenes B. Kapitan ${ }^{\mathrm{a}}$, Anna Tefa ${ }^{\mathrm{b}}$, Dewi S. Hede ${ }^{\mathrm{c}}$, Filogus N. Payon ${ }^{\mathrm{d}}$ \\ ${ }^{a}$ Fakultas Pertanian, Universitas Timor, Kefamenanu, TTU - NTT, Indonesia.email:boy57kapitan@gmail.com \\ ${ }^{b}$ Fakultas Pertanian, Universitas Timor, Kefamenanu, TTU - NTT, Indonesia.email:annatefa@roketmail.com \\ ${ }^{c}$ Fakultas Pertanian, Universitas Timor, Kefamenanu, TTU-NTT, Indonesia.email :dewiselvin@gmail.com \\ ${ }^{d}$ Laboratorium Fakultas Pertanian, Universitas Timor, Kefamenanu, TTU-NTT, Indonesia.email:glorypayon@yahoo.co.id
}

\section{Article Info}

Article history:

Received 16 Desember 2018

Received in revised form 8 Februari 2019

Accepted 17 Maret 2018

DOI:

https://doi.org/10.32938/sc.v4i02.620

\section{Keywords:}

Biochar

Lactuca sativa

Media semai

Viabilitas benih
Biomassa kayu

\section{Abstrak}

Media perkecambahan merupakan salah satu faktor yang mempengaruhi perkecambahan benih. Syarat media tanam yang baik untuk proses perkecambahan adalah bahan penyusun media yang menyediakan cukup ruang berpori untuk udara dan air. Salah satu bahan berpori yang dapat digunakan sebagai media semai benih adalah biochar. Karakteristik biochar umumnya tergantung pada kondisi temperatur pembakaran biomassa dan jenis biomassa yang digunakan. Tujuan dilakukannya penelitian adalah untuk mengetahui persentase konversi biomassa dari 3 jenis biomassa kayu menjadi biochar, karakteristik kimia biochar hasil pirolisis pada 3 temperatur yang berbeda, dan viabilitas benih selada pada media semai campuran biochar, tanah, dan kompos. Penelitian ini menggunakan rancangan acak lengkap pola faktorial yang diulang 3 kali. Faktor pertama merupakan jenis biomassa kayu yang terdiri atas 3 level yakni kayu kusambi, kayu putih, dan kayu akasia. Sedangkan faktor kedua adalah temperatur pembakaran yang terdiri atas 3 variasi suhu yakn $350{ }^{\circ} \mathrm{C}, 450{ }^{\circ} \mathrm{C}$, dan $550{ }^{\circ} \mathrm{C}$. Hasil penelitian menunjukkan bahwa persentase hasil biochar terbaik dihasilkan pada jenis biomassa kayu kusambi dengan temperatur pirolisis sebesar $350^{\circ} \mathrm{C}$. $\mathrm{pH}$ biochar bersifat alkali kecuali pada biochar kusambi dengan temperatur pirolisis $350{ }^{\circ} \mathrm{C}$. Nilai DHL tertinggi dihasilkan oleh jenis biochar kayu putih dengan temperatur pirolisis $550{ }^{\circ} \mathrm{C}$. Jenis biochar kayu putih memiliki kandungan karbon total (C-total), nitrogen $(\mathrm{N})$, fosfat $(\mathrm{P})$, dan kalium $(\mathrm{K})$ lebih besar dibanding 2 jenis biochar lainnya, sedangkan nilai KTK terbesar dihasilkan oleh jenis biochar kusambi. Daya berkecambah benih selada terbaik dihasilkan oleh jenis biochar kayu putih pada temperatur pirolisis $450{ }^{\circ} \mathrm{C}$. Secara umum jenis biochar kayu akasia memberi hasil daya berkecambah yang baik pada semua temperatur pembakaran.

\section{Pendahuluan}

Media perkecambahan merupakan salah satu faktor yang mempengaruhi perkecambahan benih (Sumiasri dan Setyowati, 2006). Media semaian benihmenentukan kualitas bibit tanaman. Media yang baik memungkinkan untuk benih yang berkecambah memiliki perakaran yang baik sehingga menghasilkan bibit tanaman yang berkualitas. Syarat media tanam yang baik untuk proses perkecambahan adalah bahan penyusun media yang menyediakan cukup ruang berpori untuk udara dan air. Media yang mempunyai pori akan membantu sistem pertumbuhan akar dalam kontak dengan larutan (air) yang diperlukan untuk pertumbuhan tanaman. Salah satu media berpori adalah arang. Arang merupakan bahan padat berpori produk pirolisis bahan organik. Arang dari bahan baku biomassa dikenali sebagai biochar. Penggunaan biochar saja tanpa media lain tidak dianjurkan karena sifat fisik biochar sekam tidak memungkinkan tanaman dapat tegak sempurna (Wuryaningsih dan Darliah, 1994). Biochar dapat memperbaiki sifat fisika, kimia, dan biologi tanah dengan memperbaiki kelembapan tanah (Novak et al., 2012), menyumbang fosfat (P) (Chan dan $\mathrm{Xu}, 2009)$, memperbaiki pH (Deska et al., 2011), meningkatkan daya hantar listrik (Niu et al., 2010), dan meningkatkan aktivitas mikroba tanah (Thies dan Rillig, 2009), sehingga menjadi optimal untuk perkecambahan benih dan pertumbuhan tanaman.

Biochar sekam sudah umum digunakan dalam komposisi media perkecambahan tanaman. Namun, biochar ini memiliki kelemahan karena memiliki derajat keasaman dan konduktivitas elektrik yang rendah, serta mempunyai luas permukaan yang kecil. Hal ini dipengaruhi oleh suhu pembakaran arang yang berkisar pada suhu 250-300 ${ }^{\circ} \mathrm{C}$. Lehman, (2007) melaporkan bahwa pembakaran biomassa pada suhu dibawah $400{ }^{\circ} \mathrm{C}$ menghasilkan arang yang mempunyai $\mathrm{pH}$ dan konduktivitas elektrik (electrical conductivity, EC) yang rendah, serta luas permukaan yang kecil. Ini berpengaruh terhadap ketersedian ion-ion mineral pada media tumbuh untuk dapat dipertukarkan dan diserap oleh permukaan akar.

Karakteristik biochar umumnya tergantung pada kondisi temperatur pembakaran biomassa dan jenis biomassa yang digunakan (Lehman, 2007). Pembakaran biomassa pada suhu tinggi akan menghasilkan nilai derajat keasaman $(\mathrm{pH})$ yang tinggi sehingga bersifat alkali (Cantrel et al., 2013, Wan et al., 2014). Cantrell et al., (2013) melaporkan bahwa feses sapi yang dipirolisis pada suhu $700{ }^{\circ} \mathrm{C}$ memiliki $\mathrm{pH}$ sebesar 10,3 . Nilai $\mathrm{pH}$ pada pirolisis feses sapi pada suhu $350{ }^{\circ} \mathrm{C}$ sebesar 8,4 sedangkan pada suhu $700{ }^{\circ} \mathrm{C}$ sebesar 9,5 . Jenis biomassa yang digunakan akan mempengaruhi kualitas biochar yang terbentuk, yakni kestabilan karbon saat diaplikasikan ke dalam media tanam. Kestabilan biochar terlihat dari rasio $\mathrm{C}: \mathrm{H}, \mathrm{O}: \mathrm{C}$ dan kandungan $\mathrm{C}$-terikat. Masing-masing sumber bahan baku akan berbeda-beda nilai stabilitas biocharnya tergantung dari kandungan selulosa, hemiselulosa, dan lignoselulosa. Sebagai komponen lignoselulosa, lignin dikelompokkan menjadi lignin kayu keras (hardwood), lignin kayu lunak (softwood), dan lignin rerumputan (herbaceous). Kusambi, akasia, dan kayu putih yang digunakan dalam penelitian ini tergolong dalam kayu keras (hardwood). Kayu kusambi, kayu kasuari, dan kayu ampupu diketahui memiliki nilai rasio $\mathrm{C}: \mathrm{H}, \mathrm{O}: \mathrm{C}$, dan kandungan $\mathrm{C}$-terikat tetap lebih baik dibanding biochar lantoro, mahoni, dan sekam padi (Berek dan Hue, 2016). Biochar dari biomassa kayu kusambi, kayu kasuari, dan kayu ampupu tergolong dalam kayu keras, memiliki stabilitas biochar yang baik dibanding lantoro (kayu lunak), dan sekam padi (herbaceous). Stabilitas biochar dalam tanah berkaitan dengan lamanya biochar terdegradasi. Ini berefek pada perbaikan struktur tanah, kapasitas pengikatan air, dan siklus nutrisi dalam jangka waktu lama dalam tanah. Kestabilan biochar memungkinkan untuk terjadi efisiensi penggunaan biochar sebagai media semai secara berulang-ulang dalam jangka waktu panjang.

Keuntungan biochar sebagai media tumbuh tanaman disebabkan oleh sumber bahan baku biomassa yang melimpah dan mudah didapatkan seperti sekam padi, batang kirinyu, kulit kayu putih, dan batang kayu. Pemanfaatan biomassa kayu sebagai bahan baku biochar lebih diarahkan pada lama bertahannya biochar di dalam tanah. Jenis kayu yang tumbuh di pulau Timor umumnya memiliki kandungan lignoselulosa dalam jumlah banyak dan juga mengakumulasikan metobolit-metabolit sekunder tertentu sebagai bentuk adaptasi terhadap lingkungan tumbuh yang kering. Metabolit-metabolit sekunder yang terkandung dapat bersifat fitostimulan dalam proses perkecambahan tanaman. Namun diketahui bahwa beberapa jenis bahan baku biochar dari kayu memiliki kandungan logam berat dan senyawa-senyawa toksik (fitotoksik) yang dapat mereduksi daya kecambah tanaman (Jones dan Sewart, 1997).

Hidrokarbon polisiklik aromatik (PAHs) dan senyawa organik mudah menguap (VOCs) terbentuk selama proses pembakaran biomassa. Senyawasenyawa ini bersifat toksik (fitotoksik) yang dapat mengkontaminasi tanah dan mempengaruhi pertumbuhan tanaman. Konsentrasi dan komposisi PAHs tergantung pada jenis biomassa dan temperatur pembakaran. PAHs dapat terbentuk pada temperatur pembakaran yang rendah (Techer et al., 2012). VOCs juga diketahui terbentuk dalam konsentrasi yang tinggi pada temperatur rendah dan banyak pada temperatur yang tinggi (Buss dan Ondrej, 2014). Polifenol hasil degradasi biomassa kayu berpotensi menjadi kontaminan pada beberapa biochar. Untuk mngeliminasi potensi toksisitas dari biochar bagi pertumbuhan tanaman maka perlu dilakukan uji pendahuluan menggunakan uji perkecambahan benih

Selada (Lactuca sativa) merupakan tanaman sayuran berdaun yang mana sangat sensitif dalam merespon adanya senyawa-senyawa fitotoksik dalam media tumbuh tanaman (Braine et al., 2012). Perkecambahan merupakan tahapan paling utama dalam siklus hidup tanaman, yang mana sangat sensitif dengan keadaan lingkungan (Kuriakose dan Prasad, 2008). Keberhasilan perkecambahan benih selada berkisar antara 40-75\%. Ini diakibatkan oleh sifat yang sangat sensitif dalam merespon perubahan $\mathrm{pH}$ dan adanya senyawasenyawa fitotoksik serta logam berat yang terkandung dalam media semai. Sifat ini menyebabkan selada digunakan secara meluas dalam uji perkecambahan di laboratorium terhadap senyawa-senyawa fitotoksik. Proses perkecambahan selada sangat dipengaruhi oleh kondisi $\mathrm{pH}$ media tanam, senyawa fitohormon, dan adanya senyawa fitotoksik. Oh et al., (2012) mengungkapkan bahwa pada $\mathrm{pH}$ biochar 4.83-5.72 menghambat perkecambahan selada, sedangkan pada $\mathrm{pH}$ di atas 7 juga berefek negatif terhadap perkecambahan selada. Derajat keasaman $(\mathrm{pH})$ media tanam yang rendah dapat menghambat kerja hormon tumbuh tanaman dan adanya senyawa-senyawa fitotoksik akan mereduksi kemampuan kecambah selada (Wyse dan Burns, 2013). Selain itu, tanaman ini menjadi tanaman rujukan dalam penelitian-penelitian tentang uji biochar terhadap perbaikan sifat fisika, kimia, dan biologi tanah (Trupiano et al., 2017). Keberhasilan perkecambahan benih menggunakan media biochar menjadi indikator awal efek kualitas biochar pada pertumbuhan tanaman (Rogovska et al., 2011). 
Pori biochar yang besar berperan dalam menyimpan air sehingga kelembaban media semai menjadi terjaga. Faktor utama perkecambahan selada adalah temperatur media tanam, yang mana pada temperatur diatas $33{ }^{\circ} \mathrm{C}$ tidak akan terjadi perkecambahan. Temperatur ideal perkecambahan selada adalah 23 ${ }^{\circ} \mathrm{C}$ (Yoshioka et al., 1998), sehingga adanya biochar sebagai bahan pengikat air dapat menurunkan dan menjaga temperatur menjadi ideal untuk perkecambahan selada.

Tujuan dilakukannya penelitian adalah untuk mengetahui persentase konversi biomassa dari 3 jenis biomassa kayu menjadi biochar, karakteristik kimia biochar hasil pirolisis pada 3 temperatur yang berbeda, dan viabilitas benih selada pada media semai campuran biochar, tanah, dan kompos.

\section{Metode}

\subsection{Waktu dan Tempat Pelaksanaan}

Penelitian ini dilakukan di Laboratorium Faperta Universitas Timor pada bulan April-November 2018. Analisis derajat keasaman $(\mathrm{pH})$ dan daya hantar listrik (DHL) dilakukan di Laboratorium Biosains Universitas Nusa Cendana. Analisis kandungan karbon $(\mathrm{C})$ total, nitrogen $(\mathrm{N})$, fosfat $(\mathrm{P})$, kalium $(\mathrm{K})$ dan kapasitas tukar kation (KTK) dilakukan di Laboratorium Kimia Tanah, Fakultas Pertanian, Universitas Nusa Cendana.

\subsection{Bahan dan Alat}

Bahan yang digunakan dalam penelitian ini adalah batang kayu kusambi (Schleichera oleosa), batang kayu akasia (Acacia denticulosa), kayu putih (Eucalyptus alba), benih selada (Lactuca sativa L.), tanah vertisol, kompos, benih selada, $\mathrm{HNO}_{3}$ Emerck, dan aquadest. Alat yang dipakai dalam penelitian ini adalah $\mathrm{pH}$ meter, conductivity meter, tanur, mortar, ayakan berukuran 50 mesh, seed tray, dan alat gelas laboratorium.

\subsection{Rancangan Penelitian}

Penelitian ini dilakukan dalam 3 tahapan. Tahapan pertama adalah uji tumbuh benih pada arang kusambi yang diberikan perlakuan suhu pembakaran pada $350{ }^{\circ} \mathrm{C}, 450{ }^{\circ} \mathrm{C}$, dan $550{ }^{\circ} \mathrm{C}$. Tahapan kedua adalah uji tumbuh benih pada arang akasia yang diberi perlakuan suhu pembakaran pada $350{ }^{\circ} \mathrm{C}, 450{ }^{\circ} \mathrm{C}$, dan $550{ }^{\circ} \mathrm{C}$. Tahapan ketiga adalah uji tumbuh benih pada arang kayu putih yang diberi perlakuan suhu pembakaran $350{ }^{\circ} \mathrm{C}, 450{ }^{\circ} \mathrm{C}$, dan $550{ }^{\circ} \mathrm{C}$. Rancangan penelitian yang digunakan adalah Rancangan Acak Lengkap (RAL) faktorial yang terdiri dari 2 faktor dengan faktor pertama adalah jenis biomassa dengan level kayu kusambi $\left(\mathrm{K}_{0}\right)$, kayu akasia $\left(\mathrm{K}_{1}\right)$, dan kayu putih $\left(\mathrm{K}_{2}\right)$. Faktor kedua adalah temperatur pembakaran dengan level biochar dengan suhu pembakaran $350{ }^{\circ} \mathrm{C}\left(\mathrm{T}_{0}\right)$, biochar dengan suhu pembakaran $450{ }^{\circ} \mathrm{C}\left(\mathrm{T}_{1}\right)$, dan biochar dengan suhu pembakaran $550{ }^{\circ} \mathrm{C}\left(\mathrm{T}_{2}\right)$. Kombinasi perlakuannya $\mathrm{K}_{0} \mathrm{~T}_{0}, \mathrm{~K}_{0} \mathrm{~T}_{1}, \mathrm{~K}_{0} \mathrm{~T}_{2}$, $\mathrm{K}_{1} \mathrm{~T}_{0}, \mathrm{~K}_{1} \mathrm{~T}_{1}, \mathrm{~K}_{1} \mathrm{~T}_{2}, \mathrm{~K}_{2} \mathrm{~T}_{0}, \mathrm{~K}_{2} \mathrm{~T}_{1}, \mathrm{~K}_{2} \mathrm{~T}_{2}$. Terdapat 9 kombinasi perlakuan yang diulangi 3 kali, sehingga terdapat 27 unit percobaan. Analisis data menggunakan SAS 9.1.

\subsection{Prosedur Kerja}

\section{a. Persiapan Arang}

Bahan uji diarangkan pada suhu $350{ }^{\circ} \mathrm{C}, 450{ }^{\circ} \mathrm{C}$, dan $550{ }^{\circ} \mathrm{C}$ pada tanurselama 15 menit. Arang uji selanjutnya dihaluskan dan disaring pada ayakan berukuran 50 mesh. Persentase hasil biochar dihitung berdasarkan rumus berikut (Sadaka et al., 2014):

$$
\% \text { biochar hasil }=\frac{m \text { biochar }}{m \text { biomassa }} \times 100 \%
$$

dengan: \% biochar hasil: massa biochar hasil pirolisis, $\mathrm{m}$ biochar: massa biochar (g), m biomassa: massa biomassa kayu (g).

b. Pengukuran nilai derajat keasaman biochar

Metode pengukuran nilai derajat keasaman biochar dimodifikasi dari Danyes et al., (2014). $0.25 \mathrm{~g}$ arang dilarutkan dalam $25 \mathrm{~mL}$ aquadest. Disentrifugasi selama 30 menit dengan kecepatan $15000 \mathrm{rpm}$. Supernatan disaring dan filtrat ditampung. $\mathrm{pH}$ meter dikalibrasi sebelum digunakan untuk mengukur $\mathrm{pH}$ filtrat.

c. Pengukuran nilai daya hantar listrik biochar

Metode pengukuran nilai daya hantar listrik biochar dimodifikasi dari Danyes et al., (2014). $0.25 \mathrm{~g}$ arang dilarutkan dalam $25 \mathrm{~mL}$ aquadest. Disentrifugasi selama 30 menit dengan kecepatan $15000 \mathrm{rpm}$. Supernatan disaring dan filtrat ditampung. Nilai DHL diukur menggunakan conductivity meter.

d. Pengukuran nilai karbon (C) total, nitrogen, $(\mathrm{N})$, fosfat $(\mathrm{P})$, kalium $(\mathrm{K})$ dan Kapasitas tukar kation (KTK) biochar.

Analisis nilai karbon total menggunakan metode pengabuan kering Analisis kandungan nitrogen menggunakan metode Kjeldhal. Pengukuran kandungan fosfat dan kalium dilakukan menggunakan metode pengabuan basah. Nilai KTK diukur menggunakan metode amonium acetat pada $\mathrm{pH}$ netral.

\section{e. Uji daya tumbuh benih}

Perlakuan pengujian menggunakan substrat tanah, arang, dan kompos dengan perbandingan 2:1:1. Benih yang dikecambahkan sebanyak 25 butir untuk setiap ulangan. Benih yang telah dikecambahkan dalam wadah plastik diletakkan pada rak dalam laboratorium benih untuk diamati proses perkecambahannya. Peubah yang diamati yaitu:

1. Potensi Tumbuh Maksimum (PTM)

Potensi tumbuh maksimum dihitung berdasarkan persentase benih yang mampu menjadi kecambah normal maupun kecambah abnormal pada pengamatan hari terakhir yaitu 7 Hari Setelah Tanam (HST) per jumlah benih yang ditanam. Potensi tumbuh maksimum dihitung dengan rumus:

$$
\operatorname{PTM}(\%)=\frac{\Sigma \text { benih yang tumbuh }}{\Sigma \text { benih yang ditanam }} \times 100 \%
$$

2. Daya Berkecambah (DB)

Pengukuran daya berkecambah benih (\%) dihitung berdasarkan persentase jumlah kecambah normal pada hitungan pertama (5 HST) dan hitungan kedua (7 HST) yang dibandingkan dengan jumlah total benih yang ditanam (ISTA, 2014).

Daya berkecambah benih dihitung dengan rumus:

$$
\begin{aligned}
& \qquad D B(\%)=\frac{\sum K N \text { Hitungan } I+\Sigma \text { KN Hitung II }}{\Sigma \text { benih yang ditanam }} \times 100 \% \\
& \text { Keterangan : } \\
& \mathrm{KN}=\text { Kecambah Normal }
\end{aligned}
$$

\section{Kecepatan Tumbuh $\left(\mathrm{K}_{\mathrm{CT}}\right)$}

Kecepatan tumbuh diukur berdasarkan persentase kecambah normal pada waktu tanam sampai akhir pengamatan (7 HST). Pengamatan dilakukan setiap hari terhadap pertambahan persentase kecambah normal dibagi dengan etmal (24 jam). Nilai etmal kumulatif dimulai saat benih ditanam sampai dengan waktu pengamatan. Kecepatan tumbuh dihitung dengan rumus:

$$
\begin{aligned}
\text { Keterangan : } & \\
\mathrm{t} & =\text { Waktu pengamatan ke- } \mathrm{i} \\
\mathrm{N} & =\text { Persentase kecambah normal setiap waktu pengamatan } \\
\mathrm{tn} & =\text { Waktu akhir pengamatan (hari ke } 7 \text { ) }
\end{aligned}
$$$$
\mathrm{K}_{\mathrm{CT}}=(\% \mathrm{KN} / \mathrm{etmal})=\sum_{0}^{\operatorname{tn}} \frac{N}{t}
$$

\section{Indeks Vigor (IV)}

Indeks vigor dihitung berdasarkan persentase jumlah kecambah normal pada hitungan pertama (first count) (5 HST) di bagi dengan jumlah benih yang ditanam. Indeks vigor dihitung dengan rumus:

$$
I V(\%)=\frac{\sum \text { kecambah normal pada hitungan pertama }}{\sum \text { benih yang ditanam }} \times 100 \%
$$

$$
550 \quad 76.00^{\mathrm{ab}} \quad 80.00^{\mathrm{a}} \quad 13.557^{\mathrm{c}} 45.33^{\mathrm{ab}}
$$

\section{Hasil dan Pembahasan \\ 3.1 Hasil}

\section{Preparasi Biochar}

Pengubahan biomassa secara termokimiawi merujuk pada perubahan fisik dan kimiawi biomassa oleh interaksi dengan panas pada keadaan yang terkontrol. Proses pirolisis biomassa dimulai dari dehidrasi, depolimerisasi, isomerisasi, aromatisasi, dekarboksilasi dan pengarangan. Hasil karbonisasi biomassa menunjukkan jumlah dan kualitas padatan residu (arang) hasil pirolisis, jumlah senyawa volatil yang dilepas serta material biomassa yang menyusut. Biomassa kayu tersusun dari banyak komponen kimia seperti selulosa, hemiselulosa, lignin, tanin, asam lemak, resin, dan senyawa-senyawa anorganik. Pirolisis akan menyebabkan struktur organik polimer kayu dari selulosa, hemiselulosa, dan lignin menjadi terputus akibat pengaruh energi panas.

Tabel 1. Rendemen biochar biomassa kayu hasil pirolisis pada suhu yang berbeda

\begin{tabular}{cccccc}
\hline No & $\begin{array}{c}\text { Jenis } \\
\text { Biomassa } \\
\text { Kayu }\end{array}$ & $\begin{array}{c}\text { Temperatur } \\
\text { pembakaran }\end{array}$ & $\begin{array}{c}\text { Bobot Biomassa } \\
(\mathrm{g})\end{array}$ & $\begin{array}{c}\text { Bobot Biochar } \\
(\mathrm{g})\end{array}$ & $\begin{array}{c}\text { Hasil } \\
\text { Biochar } \\
\%\end{array}$ \\
\hline \multirow{3}{*}{1} & Kayu putih & 350 & 2430.11 & 425.28 & 17.50 \\
& & 550 & 7397.28 & 1500.81 & 20.29 \\
& & 350 & 3019.28 & 487.37 & 16.14 \\
2 & \multirow{2}{*}{ Kusambi } & 450 & 11718.96 & 8501.48 & 72.54 \\
& & 550 & 7375.75 & 4947.02 & 67.07 \\
& & 350 & 2968.06 & 1972.24 & 66.45 \\
3 & Akasia & 450 & 2820.24 & 609.97 & 21.63 \\
& & 550 & 3512.81 & 605.44 & 17.24 \\
& & & 3588.63 & 667.22 & 18.59 \\
\hline
\end{tabular}

\section{Nilai derajat keasaman dan daya hantar listrik biochar}

Pembakaran biomassa pada suhu tinggi akan menghasilkan nilai derajat keasaman $(\mathrm{pH})$ yang tinggi sehingga bersifat alkali. Daya hantar listrik biochar merupakan taraf kejenuhan garam di dalam biochar hasil pirolisis biomassa kayu pada suhu yang berbeda. Nilai DHL berkorelasi dengan nilai kation dan anion yang terkandung dalam biochar. Nilai DHL yang tinggi menunjukkan tingginya kandungan garam yang terlarut dalam biochar. Kation-kation pada permukaan biochar terikat secara ikatan elektrostatis. Ikatan ini terbentuk karena gaya tarik menarik antara ion-ion pada permukaan biochar. Biochar mengandung oksida seperti $\mathrm{CaCO}_{3}, \mathrm{CaO}, \mathrm{MgO}, \mathrm{K}_{2} \mathrm{Ca}\left(\mathrm{CO}_{3}\right)_{2}$. Kandungan senyawa-senyawa karbonat ini memberikan efek meningkatkan nilai $\mathrm{pH}$ biochar menjadi lebih alkali. 


\section{Kandungan C total, N, P, K, dan KTK biochar}

Menurut Gaskin et al., (2008), kandungan nutrisi dalam biochar tergantung dari biomassanya. Biochar kayu putih memiliki nilai C-total, nitrogen, fosfat, dan kalium yang lebih besar dibanding kayu kusambi dan kayu akasia. Terlihat bahwa semakin besar temperatur pirolisis maka semakin kecil nilai C-total.

Kandungan nitrogen semakin menurun seiring kenaikan temperatur pirolisis.

Nilai fosfat dan kalium serta kapasitas tukar kation pada biochar semakin meningkat seiring kenaikan temperatur pirolisis.

\begin{tabular}{ccccc}
\multicolumn{6}{c}{ Tabel 2. Nilai pH dan DHL biochar hasil pirolisis } \\
\hline \multirow{2}{*}{ No } & $\begin{array}{c}\text { Jenis Biomassa } \\
\text { Kayu }\end{array}$ & $\begin{array}{c}\text { Temperatur } \\
\text { pembakaran }\end{array}$ & $\mathrm{pH}$ & $\begin{array}{c}\text { Nilai DHL } \\
(\mu \mathrm{S} / \mathrm{cm})\end{array}$ \\
\hline \multirow{2}{*}{1} & Kayu putih & 350 & 7.96 & 507 \\
& & 450 & 9.81 & 997 \\
\multirow{2}{*}{2} & 550 & 9.34 & 2440 \\
& \multirow{4}{*}{ Kusambi } & 350 & 6.95 & 249.7 \\
& & 450 & 8.40 & 235.8 \\
3 & \multirow{2}{*}{ Akasia } & 350 & 8.27 & 253.4 \\
& & 450 & 7.95 & 283.4 \\
& & 550 & 9.11 & 408 \\
\hline
\end{tabular}

Tabel 3. Kandungan C total, N, P, K, dan KTK biochar hasil pirolisis

\begin{tabular}{cccccccc}
\hline \multirow{2}{*}{ No } & $\begin{array}{c}\text { Jenis Biomassa } \\
\text { Kayu }\end{array}$ & $\begin{array}{c}\text { Temperatur } \\
\text { pembakaran }\end{array}$ & $\begin{array}{c}\text { C-total } \\
(\%)\end{array}$ & $\begin{array}{c}\text { N } \\
(\%)\end{array}$ & $\begin{array}{c}\text { P } \\
(\%)\end{array}$ & $\begin{array}{c}\text { K } \\
(\%)\end{array}$ & $\begin{array}{c}\text { KTK } \\
(\mathrm{me} / 100 \mathrm{~g})\end{array}$ \\
\hline \multirow{3}{*}{1} & \multirow{3}{*}{ Kayu putih } & 350 & 67.30 & 0.45 & 0.33 & 0.76 & 18.48 \\
& & 450 & 66.45 & 0.45 & 0.4 & 0.8 & 18.70 \\
& & 550 & 65.88 & 0.45 & 0.4 & 0.8 & 20.22 \\
2 & \multirow{2}{*}{ Kusambi } & 350 & 63.55 & 0.37 & 0.28 & 0.67 & 18.91 \\
& & 450 & 59.44 & 0.33 & 0.28 & 0.68 & 20.00 \\
& & 550 & 59.23 & 0.32 & 0.33 & 0.73 & 20.22 \\
3 & & 350 & 67.42 & 0.42 & 0.32 & 0.71 & 18.26 \\
& Akasia & 450 & 65.05 & 0.38 & 0.33 & 0.75 & 18.70 \\
& & 550 & 61.73 & 0.37 & 0.37 & 0.79 & 19.57 \\
\hline
\end{tabular}

\section{Viabilitas benih}

Viabilitas benih adalah daya hidup benih yang ditunjukkan dengan gejala pertumbuhan atau gejala metabolisme (Sadjad, 1994). Perkecambahan benih adalah muncul dan berkembangnya struktur terpenting dari embrio benih serta kecambah tersebut menunjukkan kemampuan untuk berkembang menjadi tanaman normal pada kondisi lingkungan yang menguntungkan. Viabilitas benih menunjukkan daya hidup benih, aktif secara metabolik dan memiliki enzim yang dapat mengkatalis reaksi metabolik yang diperlukan untuk perkecambahan dan pertumbuhan kecambah (Copeland dan McDonald, 2001).

Tabel 4. Viabilitas benih selada

\begin{tabular}{|c|c|c|c|c|c|c|}
\hline No & $\begin{array}{c}\text { Jenis } \\
\text { Biomassa } \\
\text { Kayu } \\
\end{array}$ & $\begin{array}{l}\text { Temperatur } \\
\text { pembakaran }\end{array}$ & $\begin{array}{c}\text { Potensi } \\
\text { tumbuh } \\
\text { maksimum }\end{array}$ & $\begin{array}{c}\text { Daya } \\
\text { berkecambah }\end{array}$ & $\begin{array}{c}\text { Kecepatan } \\
\text { tumbuh }\end{array}$ & $\begin{array}{l}\text { Indeks } \\
\text { Vigor }\end{array}$ \\
\hline \multirow{3}{*}{1} & \multirow{3}{*}{$\begin{array}{l}\text { Kayu } \\
\text { putih }\end{array}$} & 350 & $62.67^{\mathrm{abc}}$ & $29.33^{\mathrm{bc}}$ & $25.137^{\mathrm{a}}$ & $50.67^{\mathrm{ab}}$ \\
\hline & & 450 & $80.00^{\mathrm{a}}$ & $84.00^{\mathrm{a}}$ & $21.820^{\mathrm{ab}}$ & $50.67^{\mathrm{ab}}$ \\
\hline & & 550 & $62.67^{\mathrm{abc}}$ & $21.33^{\mathrm{c}}$ & $13.000^{\mathrm{c}}$ & $53.33^{\mathrm{a}}$ \\
\hline \multirow{3}{*}{2} & & 350 & $45.33^{\mathrm{bcd}}$ & $45.33^{\mathrm{abc}}$ & $26.970^{\mathrm{a}}$ & $16.00^{\mathrm{b}}$ \\
\hline & \multirow[t]{2}{*}{ Kusambi } & 450 & $66.67^{\mathrm{abc}}$ & $33.33^{\mathrm{bc}}$ & $21.827^{\mathrm{ab}}$ & $56.00^{\mathrm{a}}$ \\
\hline & & 550 & $20.00^{\mathrm{d}}$ & $82.67^{\mathrm{a}}$ & $26.377^{\mathrm{a}}$ & $40.00^{\mathrm{ab}}$ \\
\hline \multirow{2}{*}{3} & \multirow{2}{*}{ Akasia } & 350 & $40.00^{\text {cd }}$ & $68.00^{\mathrm{ab}}$ & $18.423^{\mathrm{b}}$ & $42.67^{\mathrm{ab}}$ \\
\hline & & 450 & $85.33^{\mathrm{a}}$ & $64.33^{\mathrm{abc}}$ & $19.050^{\mathrm{b}}$ & $41.33^{\mathrm{ab}}$ \\
\hline
\end{tabular}

\subsection{Pembahasan}

Selama proses pirolisis, biomassa kayu akan terdekomposisi dan mulai kehilangan bobot massa akibat penyusutan dan penguapan air dan senyawa mudah menguap. Pemutusan ikatan oleh panas dimulai dari struktur hemiselulosa, selulosa, lignin, dan senyawa-senyawa ekstraktif (tanin, asam lemak, dan resin). Hemiselulosa (umumnya xilan) putus pada temperatur 200$320{ }^{\circ} \mathrm{C}$, diikuti oleh selulosa pada temperatur $280-360{ }^{\circ} \mathrm{C}$ dan lignin pada temperatur $300-550{ }^{\circ} \mathrm{C}$ (Stefanidis et al., 2014). Stefanidis et al., (2014) juga melaporkan bahwa senyawa-senyawa yang terbentuk sebagai produk pirolisis dapat dikelompokkan menjadi hidrokarbon aromatik (AR), hidrokarbon alifatik (ALI), senyawa-senyawa fenolat (PH), furan (FUR), asam (AC), ester (EST), alkohol (AL), eter (ETH), aldehida (ALD), keton (KET), hidrokarbon polisiklik aromatik (PAH), gula (SUG), dan senyawa yang mengandung nitrogen (NIT).

Hasil penelitian terdahulu pada biomassa kayu menunjukkan bahwa semakin besar temperatur pirolisis menurunkan persentase hasil biochar (Titiladunayo et al., 2012). Penelitian ini menunjukkan bahwa pada biomassa kayu kusambi memperlihatkan pola yang sama dengan penelitian Titiladunayo et al., (2012) pada kayu A. africana, dan M. excelsa. Hasil biochar dari bahan baku kayu kusambi, akasia, dan kayu putih makin menurun dengan naiknya temperatur pirolisis. Rendemen biochar terbesar dihasilkan dari biomassa kayu kusambi. Ini menunjukkan bahwa kayu kusambi bersifat kayu keras (lignin hardwood). Lignoselulosa yang terkandung dalam kayu kusambi diduga belum putus semuanya. Lignoselulosa tersusun oleh 3 polimer yakni selulosa, hemiselulosa dan lignin serta senyawa-senyawa lain seperti senyawa kelompok asetil, mineral-mineral, dan senyawa-senyawa fenolat. Komponen utama pada lignoselulosa adalah selulosa. Unit berulang selulosa disusun oleh disakarida selubiosa yang strukturnya tersusun oleh ikatan hidrogen intramolekular dan intermolekular yang mengikat erat unit-unit glukosa. Diduga tingginya deraja kristalinitas selulosa pada kayu kusambi mengakibatkan persentase hasil biochar menjadi tinggi dibanding kayu akasia dan kayu putih (Tabel 2).

Naiknya temperatur membuat senyawa volatil kayu makin besar dilepaskan. Semakin besar suhu pirolisis, maka semakin besar jumlah Caromatik (C-siklik) yang terbentuk dari putusnya ikatan -C-C- non aromatik dari lignoselulosa, selulosa, hemiselulosa, dan lignin kayu. Putusnya ikatan -C$\mathrm{C}$ - non aromatic akan terkondensasi menjadi -C-C- aromatic. Ini akan mengakibatkan nilai $\mathrm{C}$-total menjadi berkurang seiring naiknya temperatur pembakaran (Tabel 3). Selain itu hilangnya gugus fungsional $-\mathrm{OH}$ selama pembakaran dan terputusnya ikatan $\mathrm{C}$ - dengan $\mathrm{O}$ dan $\mathrm{H}$ sehingga meningkatkan nilai $\mathrm{C}$ yang terkandung dalam biochar. Kandungan fosfat yang tinggi seiring naiknya temperatur pirolisis diakibatkan oleh tidak hilangnya unsur ini selama volatilization. Kandungan kalium yang tinggi seiring kenaikan temperatur pembakaran diakibatkan oleh adanya oksida $\mathrm{K}_{2} \mathrm{Ca}\left(\mathrm{CO}_{3}\right)_{2}$ yang putus seiring kenaikan temperatur pirolisis. Nilai KTK yang tinggi menunjukkan tingginya potensi muatan negatif pada gugus-gugus fungsional dipermukaan biochar.

$\mathrm{pH}$ biochar hasil penelitian bersifat alkali. Ini terjadi karena selama proses karbonisasi, gugus fungsional yang bersifat asam hilang dan garamgaram dari unsur-unsur alkali dan alkali tanah terbentuk. Pada temperatur rendah, gugus fungsional karboksilat dan fenolat akan putus. Naiknya temperatur pada $300-500{ }^{\circ} \mathrm{C}$ dan $700{ }^{\circ} \mathrm{C}$ akan memutus $-\mathrm{COOH}$, dan $-\mathrm{OH}$ (Yuan et al., 2011). Turunnya nilai $\mathrm{pH}$ biochar kayu putih dan kusambi yang dipirolisis pada temperatur $550{ }^{\circ} \mathrm{C}$ (Tabel 2) diduga akibat kondensasi dari senyawa-senyawa asam (AC) dan aldehida (ALD) pada biochar. Penelitian ini memberikan hasil yang sedikit berbeda dengan penelitian Oh et al., (2012) mengungkapkan bahwa pada $\mathrm{pH}$ biochar 4,83-5,72 menghambat perkecambahan selada, sedangkan pada $\mathrm{pH}$ di atas 7 juga berefek negatif terhadap perkecambahan selada. Hasil penelitian menunjukkan bahwa pada $\mathrm{pH}$ 9,$81 ; 8,27 ; 9,71$ perkecambahan selada menunjukkan hasil yang optimum dilihat dari data daya berkecambah (Tabel 4.). Namun, dalam rentang pH 6,959,11 memperlihatkan efek negatif dari perkecambahan selada. Hasil ini berbeda dengan penelitian Gasco et al., (2016) yang mengungkapkan pH ideal untuk perkecambahan selada adalah sekitar 7 .

DHL yang terukur dalam biochar menunjukkan jumlah ion garam yang terkandung dalam biochar. Hasil penelitian menunjukkan bahwa semakin besar temperatur pembakaran mengakibatkan nilai DHL biochar semakin besar. Ini sejalan dengan penelitian Cantrell et al., (2012); Claoston et al., (2014); Rehrah et al., (2014); dan Olszyk et al., (2018). Peningkatan DHL ini diduga berkaitan peningkatan konsentrasi residu atau abu yang disebabkan oleh hilangnya bahan yang menguap selama pirolisis. Biomassa kayu putih memiliki nilai DHL yang tinggi $(507-2440 \mu \mathrm{S} / \mathrm{cm})$ dibandingkan dengan kayu akasia $(283,4-644 \mu \mathrm{S} / \mathrm{cm})$ dan kayu kusambi $(235,8-253,4 \mu \mathrm{S} / \mathrm{cm})$. Nilai DHL ini berbanding terbalik dengan persentase hasil biochar, yang mana kayu kusambi memiliki persentase hasil biochar terbesar diikuti kayu akasia dan kayu putih. Ini menunjukkan bahwa biochar kayu putih hasil pirolisis mengandung sejumlah besar garamgaram $\mathrm{CaCO}_{3}, \mathrm{CaO}, \mathrm{MgO}, \mathrm{K}_{2} \mathrm{Ca}\left(\mathrm{CO}_{3}\right)_{2}$ yang terputus ikatannya, namun tidak hilang selama proses pirolisis sehingga menghasilkan nilai daya hantar listrik yang besar.Daya hantar listrik biochar merupakan taraf kejenuhan garam di dalam biochar hasil pirolisis biomassa kayu pada suhu yang berbeda. Nilai DHL berkorelasi dengan nilai kation dan anion yang terkandung dalam biochar. Nilai DHL yang tinggi menunjukkan tingginya kandungan garam yang terlarut dalam biochar. Kation-kation pada permukaan biochar terikat melalui ikatan elektrostatis. Ikatan ini terbentuk karena gaya tarik menarik antara ion-ion pada permukaan biochar. Biochar mengandung oksida seperti $\mathrm{CaCO}_{3}, \mathrm{CaO}, \mathrm{MgO}$, $\mathrm{K}_{2} \mathrm{Ca}\left(\mathrm{CO}_{3}\right)_{2}$. Kandungan senyawa-senyawa karbonat ini memberikan efek meningkatkan nilai $\mathrm{pH}$ biochar menjadi lebih alkali. Kation yang terkandung dalam biochar kayu antara lain $\mathrm{Ca}, \mathrm{Mg}, \mathrm{Na}$, dan $\mathrm{K}$.

Pemanfaatan biochar yang ditambahkan dengan tanah dan kompos sebagai media semai mengakibatkan adanya perubahan keadaan fisik dan kimia serta kondisi nutrisi dalam media semai. Daya berkecambah selada diduga berkorelasi dengan nilai DHL biochar (Tabel 2). Terlihat bahwa daya berkecambah selada paling rendah $(21,33 \%)$ pada nilai DHL biochar tertinggi yakni $2440 \mu \mathrm{S} / \mathrm{cm}$. Ini menunjukkan bahwa keadaan terlalu salin tidak mendukung proses perkecambahan namun menghambat perkecambahan.

Potensi tumbuh maksimum (PTM) adalah kemampuan benih untuk tumbuh dalam keadaan normal maupun abnormal dengan batas minimal keluarnya akar dari benih. Hasil penelitian menunjukkan bahwa potensi tumbuh maksimum pada biomassa kayu putih dan akasia pada temperatur pembakaran $450^{\circ} \mathrm{C}$ adalah $80 \%$ dan $85,33 \%$. Daya berkecambah (DB) adalah total kecambah normal yang dapat hidup pada kondisi optimal. Daya berkecambah merupakan tolak ukur viabilitas potensial $(\mathrm{Vp})$ karena nilai daya berkecambah mensimulasi persentase benih yang mampu tumbuh dan berproduksi normal dalam kondisi optimum. Daya berkecambah pada biomassa kayu putih dengan temperatur pembakaran $4500^{\circ} \mathrm{C}$ adalah sebesar $84 \%$, namun tidak berbeda nyata dengan biomassa kusambi dan akasia pada temperatur pembakaran $550{ }^{\circ} \mathrm{C}$. Daya berkecambah untuk kayu putih terbaik pada suhu $450{ }^{\circ} \mathrm{C}$, sedangkan kayu kusambi dan kayu akasia pada suhu $550{ }^{\circ} \mathrm{C}$. Daya berkecambah yang dibawah $80 \%$ menunjukkan bahwa benih selada mengalami dormansi. Rendahnya daya 
berkecambah hasil penelitian pada jenis kayu putih tidak mengindikasikan kemunduran benih namun menunjukkan adanya efek dormansi dari biochar kayu putih. Gasco et al., (2016) mengungkapkan adanya penghambatan perkecambahan selada oleh biochar dari kayu. Hasil yang berbeda dilaporkan dalam penelitian ini dan penelitian Olszyk et al., (2018). Beberapa senyawa dalam biochar diketahui berpotensi untuk menghambat maupun memacu perkecambahan benih dan pertumbuhan tanaman. Senyawa-senyawa seperti crystalline silica, dioxin, polyaromatichydrocarbons (PAHs) dan senyawa fenolat dalam biochar diketahui berefek negatif terhadap tanaman. Kecepatan tumbuh pada biomassa kusambi pada temperatur pembakaran $350{ }^{\circ} \mathrm{C} 26,97$ $\% /$ etmal tidak berbeda nyata dengan biomassa kusambi pada temperatur pembakaran $550{ }^{\circ} \mathrm{C}$ dan biomassa kayu putih pada temperatur pembakaran 350 ${ }^{\circ} \mathrm{C}$. Indeks vigor pada biomassa kusambi pada temperatur pembakaran $450{ }^{\circ} \mathrm{C}$ $56 \%$ tidak berbeda nyata dengan biomassa kayu putih pada temperatur $550{ }^{\circ} \mathrm{C}$.

Pemanfaatan biochar sebagai media semai menunjukkan hasil yang moderat. Ini menunjukkan bahwa biochar dapat digunakan sebagai media perkecambahan benih karena biochar memperbaiki aggregasi, meningkatkan porositas, aerasi, dan kapasitas ikat air sehingga mampu mendukung perkecambahan benih selada. Biochar mempunyai pori dalam partikelnya (intrapores), sehingga memiliki ruang yang besar dalam menyimpan air dalam ruang-ruang pori antar partikel (interpores). Pori biochar yang besar berperan dalam mengikat dan menyimpan air sehingga kelembaban media semai menjadi terjaga. Ukuran partikel biochar yang halus dapat mengisi pori-pori di antara partikel tanah sehingga mengurangi ukuran pori dan mengubah bentuk interpore. Adanya ion-ion oksida pada biochar mengakibatkan muatan permukaannya menjadi negatif dan juga luasnya area permukaan memungkinkan biochar meningkatkan kapasitas ikat air dalam media semai sehingga kondisi media semai menjadi optimal untuk perkecambahan benih selada.

\section{Simpulan}

Dari hasil penelitian diatas maka dapat disimpulkan beberapa hal sebagai berikut, persentase hasil biochar terbaik dihasilkan pada jenis biomassa kayu kusambi dengan temperatur pirolisis sebesar $350^{\circ} \mathrm{C}$. $\mathrm{pH}$ biochar bersifat alkali kecuali pada biochar kusambi dengan temperatur pirolisis $350{ }^{\circ} \mathrm{C}$. Nilai DHL tertinggi dihasilkan oleh jenis biochar kayu putih dengan temperatur pirolisis $550{ }^{\circ} \mathrm{C}$. Jenis biochar kayu putih memiliki kandungan $\mathrm{C}$-total, $\mathrm{N}, \mathrm{P}$, dan $\mathrm{K}$ lebih besar dibanding 2 jenis biochar lainnya, sedangkan nilai KTK terbesar dihasilkan oleh jenis biochar kusambi. Daya berkecambah benih selada terbaik dihasilkan oleh jenis biochar kayu putih pada temperatur pirolisis $450{ }^{\circ} \mathrm{C}$. Secara umum jenis biochar kayu akasia memberi hasil daya berkecambah yang baik pada semua temperatur pembakaran.

\section{Pustaka}

Berek A.K., Hue N.V. 2016. Characterization of biochars and their use as an amandment to acid soils. Soil Sci. 181: 412-426

Bourke J., Manley-Harris M., Fushimi C., Dowaki K., Nunoura T., Antal Jr M.J., 2007. Do all carbonized charcoals have the same chemical structure? 2. A model of the chemical structure of carbonized charcoal. Ind. Eng. Chem. Res. 46: 5954-5977

Braine J.W., urcio G.R., Wachowicz C.M., Hansel F.A. 2012. Allelopathic effects of Araucaria angustifolia needle extracts in the growth of Lactuca sativa seeds. Journal of Forest Research 17: 440-445

Buss, W., Ondrej, M. 2014. Mobile organic compounds in biochar - A potential source of contamination-phytotoxic effects on cress seed (Lepidium sativum) germination. J Environ Manage. 137: 111-119

Cantrell K. B., Hunt P. G., Uchimiya M., Novak J. M., Ro K. S., 2013. Impact of pyrolisis temperature and manure source on physicochemical characteristics of biochar. J.biortech. Vol 107: 419-428

Chan, K. Y., Xu, Z. 2010. Biochar: Nutrient properties and their enrichment. In biochar for environmental management: Science and technology, Ed. Lehman $J$, and Joseph $S$. London (UK): Earthscan

Claoston, N., Samsuri, A. W., Ahmad Husni, M. H., Mohd Amran, M. S. 2014 Effects of pyrolysis temperature on the physicochemical properties of empty fruit bunch and rice husk biochars. Waste Management \& Research. 32 (4): 331-339

Copeland, L. O., Mc Donald, M. B. 2001. Principles of seed science and technology. London (UK): Kluwer Academic Publishers

Denyes, M. J., Parisien, M. A., Rutter, A., Zeeb, B. A. 2014. Physical, chemical, and biological characterization of six biochars produced for the remediation of contaminated sites. J Vis Exp. 93:52183

Deska, J., Jankowski, K., Bombik, A., Jankowska, J. 2011. Effect of growing medium $\mathrm{pH}$ on germination and initial development of some grassland plants. Acta Scientiarum Polonorum Agricultura. 10: 45-56.

Gasco, G., Cely, P., Paz-Ferreiro, J., Plaza, C., Mendez, A. 2016. Relation between biochar properties and effect on seed germination and plant development. Biological agriculture \& Horticulture. 32: 237-247

Gaskin, J. W., Steiner, C., Harris, K., Das, K. C., Bibens, B. 2008. Effect of low temperature pyrolysis conditions on biochar for agriculture use. Transaction of the Asabe. 51: 2061-2069

[ISTA] International Seed testing Association. 2014. International Rules for Seed Testing. ISTA. Basserdorf
Jones K., Sewart A. 1997. Dioxins and furans in sewerage sludge: a review of their occurance and sources in sludge and of their environmental fate, behaviour, and significance in sludge-amanded agricultural system. Critical Reviews in Environmental Science and Technology 27:1-85.

Kuriakose S.V., Prasad M.N.V. 2008. Cadmium stress affects seed germination and seedling growth in Sorghum bicolor (L.) Moench by charging the activities of hydrolizing enzymes. Plant Growth Regulation. 54:143-156.

Lehman J., 2007. A handful of carbon. Nature. Vol 447:143-144

Lehman J., Joseph S., 2009. Biochar for environmental management: an introduction. In Biochar for environmental management: Science and Technology; Lehman J., Joseph S., Eds. Earthscan. London

Novak, J. M., Busscher, W. J., Watts, D. W., Amonette, J., Ippolito, J. A. Lima, I. M., Gaskin, J., Das, K. C., Steiner, C., Ahmedna, M., Rehrah, D., Schomberg, H. 2012. Biochars impact on soil-moisture storage in an ultisol and two aridisols. Soil Science. 177: 310-320

Oh T.K., Shinogi Y., Chikushi J., Lee Y.H., Choi B. 2012. Effect of aqueous extract of biochar on germination and seedling growth of lettuce (Lactucasativa L.). J. Fac. Agr, kyushu Univ. 57 (1): 55-60.

Olszyk, D. M., Shiroyama, T., Novak, J. M., Johnson, M. G. 2018. A rapid-test for screening biochar effects on seed germination. Commun Soil Sci Plant Anal. 49 (16): 2025-2041

Rehrah, D., Reddy, M. R., Novak, J. M., Bansode, R. R., Schimmel, K. A., Yu, J., Watts, D. W., Ahmedna, M. 2014. Production and characterization of biochars from agricultural by-products for use in soil quality enhancement. Journal of analytical and applied pyrolysis. 108: 301-309

Rogovska, N., Laird, D., Cruse, R. M., Trabue, S., Heaton, E. 2011. Germination test for assesing biochar quality. Journal of environmental quality. 41: 1014-1022

Ryder, E.J. 2006. Lettuce, p.377-379. In M. Blcak, J.D. Bewley, and P. Halmer (eds.). The encylopedia of seeds science, technology and uses. $\mathrm{CAB}$ International. Wallingford. UK.

Sadaka, S., Sharara, M.A., Ashworth, A., Keyser, P., Allen, F., Wright, A. 2014. Characterization of biochar from switchgrass carbonization. Energies. 7: 548-567. Doi: 10.3390/en7020548

Sadjad, S. 1994. Kuantifikasi Metabolisme Benih. Jakarta (ID): PT. Gramedia Widiasarana Indonesia

Stefanidis, S. D., Kalogiannis, K. G., Illiopoulou, E. F., Michailof, C. M., Pilavachi, P. A., Lappas, A. A. 2014. A study of lignocellulosic biomass pyrolysis via the pyrolysis of cellulose, hemicellulose, and lignin. J. Anal. Appl. Pyrolysis. 105: 143-150.

Sumiasri N., Setyowati, N., 2006. Pengaruh beberapa media pada pertumbuhan bibit eboni (Diospyros celebica Bakh) melalui perbanyakan biji. Biodiversitas. 7(3):260-263.

Titiladunayo, I. F., McDonald, A. G., Fapetu, O. P. 2012. Effect of temperature on biochar product yield from selected lignocellulosic biomass in a pyrolysis process. Waste Biomass Valor. 3: 311-318

Thecher, D., Martinez-Chois, C., Laval-Gilly, P., Henry, S., Bennasroune, A., D’Innocenzo, M., Falla, J. 2012. Assesment of Miscanthus $x$ giganteus for rhizoremediation of long term PAH contaminated soils. Appl Soil Ecol. 62: 42-49

Thies, J. E., Rillig, M. C. 2009. Characteristic of biochar: Biological properties. In biochar for environmental management: Science and technology, Ed. Lehman J, and Joseph S. London (UK): Earthscan

Trupiano D., Cocozza C., Baronti S., Amendola C., Vaccari F.P., Lustrato G., Lonardo S.D., Fantasma F., Tognetti R., Scippa G.S. 2017. The effects of biohar and its combination with compost on lettuce (Lactuca Sativa L.) growth, soil properties, and soil microbial activity and abundance. International Journal of Agronomi.

Wan Q., Yuan J.I.I., Xu R.K., Li X.I.I. 2014. Pyrolisis temperature influences ameliorating effects on acidic soil. Environ. Sci. Pollut. Res. Int. 21 2486-2495

Wuryaningsih S., Darliah. 1994. Pengaruh media sekam padi terhadap pertumbuhan tanaman hias pot Spathiphllum. Bul. Penel. Tan. Hias II (2) : 119-129

Wyse S.V., Burns B.R. 2013. Effects of Agathis australis (New Zealand kauri) leaf litter on germination and seedling growth differs among plant spesies. New Zealand Journal of Ecology. 37 (2): 178-183.

Yuan J. H., Xu R. K., Zhang H. 2011. The forms of alkalis in the biochar produced from crop residues at different temperatures. Bioresour. Technol. 102:3488-3497

Yoshioka T., Endo T., Satoh S. 1998. Restoration of seed germination at supraoptimal temperatures by fluridone, an inhibitor of abscisic acid biosynthesis. Plant Cell Physiol. 39:307-312. 